\title{
Key Issues in IFIP-SIG9.2.2 Approaches to Ethics of Computing
}

\author{
Jacques Berleur \\ Institut d'Informatique, Facultés Universitaires Notre-Dame de la Paix, Namur, Belgium
}

jberleur@info.fundp.ac.be

Key words: Codes of Ethics/Conduct, Curricula, Educational Programmes, IFIP, Ethics, Ethical issues, Law, Self-regulation, Spaces for Discussion

Abstract: Within IFIP ethics has been a preoccupation for a long time. Debate started formally in 1988 about a proposed international 'Code of Ethics'. The 1992 General Assembly concluded that the time was not ripe to adopt such a Code and asked a TC9 Task Force to provide recommendations. First, a full analysis of the current codes of IFIP member societies was undertaken. This enlightened the major deontological professional issues, such as respectful general attitude, conscientiousness, competence, promotion of privacy and confidentiality, and transparency of information. A special interest group (SIG9.2.2) was established in 1994 to support the creation of 'spaces for discussion' where ethical debate could be promoted and supported throughout IFIP and other constituencies. In a second phase, SIG9.2.2 confronted ethics and the governance of the Internet. It published a monograph that developed the main Internet-related issues that had appeared in new charters, commandments, codes and guidelines. The third phase focuses on the relationship between ethics and self-regulation. Our conclusions are that matters of interest to business and commerce tend to have legal force and regulation, but the real principles and issues of ethics tend still to be subject to no legal force. Society needs to confront this.

The original version of this chapter was revised: The copyright line was incorrect. This has been corrected. The Erratum to this chapter is available at DOI: 10.1007/978-0-387-35663-1_34 


\section{INTRODUCTION}

When speaking about computers and ethics everybody quotes James Moor:

"computer ethics is the analysis of the nature and social impact of computer technology and the corresponding formulation and justification of policies for the ethical use of such technology." (Moor 1985)

Without mentioning specific ethical issues, Moor insisted that computer ethics must involve technology and substantial scientific and technological evaluation. In his perspective it is difficult to make a clear distinction between computer ethics and computers and society issues. Other influential authors were Deborah Johnson (Johnson 1985; 1994; 2001) and Joseph Weizenbaum. The latter explicitly touched upon the question of ethics, indicating the types of research that he would not undertake, except after careful consideration and with defined limits (Weizenbaum 1976). Similar preoccupation was noted in the ACM Computing Classification Systems under 'Computing Profession' - but the word ethics does not appear explicitly before 1991. Amongst curriculum proposals, an ACM/IEEE-CS Task Force in 1991 proposed a specific module on 'Social, Ethical, and Professional Issues' covering topics like the historical and social context of computing, responsibilities of the computing professional, and intellectual property rights (ACM/IEEE-CS 1990). Other modules have been added in the 2001 ACM/IEEE-CS proposal (ACM/IEEE-CS 2001).

In this paper, I will initially consider the most recent proposals of curricula, which are the structure that specialists find suitable for the field of Ethics of computing (my preferred term). I will then confront, from experience that we have in IFIP since 1988, theory and practice, and derive recommendations for defining the most urgent ethical issues in computing today, and those considered worthy of a specific educational programme. I will outline the main themes that appear in textbooks and reflect current thinking. IFIP is an academic and professional body and my reflection will be mostly at that level.

\section{RECENT STRUCTURED PROPOSALS IN CURRICULA FOR COMPUTER SCIENTISTS}

The widely publicised report 'Consequences of Computing: A Framework for Teaching the Social and Ethical Impact of Computing' tries to link the topics of ethical analysis and the levels of social analysis (ImpactCS 1996). 
The proposal exhibits certain weaknesses - the heterogeneity of some categories in the levels of social and the unclear distinction between responsibility and ethical issues (Berleur 1996). Nevertheless, their grid, which is proposed for different technologies such as Electronic Communication, Medical Technology and Artificial Intelligence, helps teachers and students remain open-minded about the main issues associated with specific uses of ICT. It allows the mapping of Levels of Social Analysis (individuals, communities and groups, organisations, cultures, instiutional sectors, nations and global) against a range of Topics of Ethical Analysis (responsibilities and ethical issues). The main idea is that in discussing problems people may acquire desirable social and ethical skills. However, the ethical issues which are covered: individual and professional responsibilities, and more specifically quality of life, use of power, risks and reliability, property rights, privacy, equity and access, honesty and deception, are in a way privileged. I recognise that most of those issues have an ethical content, but I do not know why those categories were chosen and not others.

Table 1. Social and professional issues

\begin{tabular}{llc}
\hline ITEM & TOPIC & HOURS \\
\hline SP1 & History of computing & 1 \\
SP2 & Social context of computing & 3 \\
SP3 & Methods and tools of analysis & 2 \\
SP4 & Professional and ethical responsibilities & 3 \\
SP5 & Risks/liabilities of computer-based systems & 2 \\
SP6 & Intellectual property & 3 \\
SP7 & Privacy and civil liberties & 2 \\
SP8 & Computer crime & \\
SP9 & Economic issues in computing & \\
SP10 & Philosophical frameworks & \\
\hline
\end{tabular}

In 'Computing Curricula 2001', the Social and Professional Issues identified in 1991 have been considerably expanded, although they represent only 16 of the 280 core hours (ACM/IEEE-CS 2001). They are shown in Table 1. Even the last three categories, although very important, are elective hours.

These two curriculum examples illustrate the convergence of opinion about the key topics associated with the ethics of computing: professional and ethical responsibilities, risks and liabilities (and reliability), intellectual property, and privacy and civil liberties.

To complement this overview, Table 2 illustrates the topics covered in eleven Handbooks since 1985, Moor's publication date (Johnson 1985; 1995; 2001), (Ermann 1990), (Kallman 1993), (Forester 1994), (Oz 1994), (Johnson-Nissenbaum 1995), (Kizza 1998), (Spinello 2000), (Langford 2000). 
Table 2. Books on ethics of computing

\begin{tabular}{lc}
\hline TOPIC & Included in HANDBOOKS \\
\hline Privacy and security & 10 \\
Theory & 9 \\
Software ownership, Copyright, IPR & 8 \\
Liabilities (Defective programs) & 7 \\
Codes and Professional ethics & 7 \\
Legal issues & 5 \\
Computer crime & 4 \\
Hacking, Viruses & 4 \\
Power, Democracy & 4 \\
Quality of worklife & 3 \\
Justice (distribution of work) - Employment , Third & 3 \\
World, AI & \\
Whistle blowing & 2 \\
AI, Expert systems & 2 \\
Networked world & 2 \\
Free speech, Control of content & 2 \\
Internet Governance and regulation & 1 \\
Quality of personal life & 1 \\
Strategic Defence Initiative (SDI) & 1 \\
Risks of computing & 1 \\
Pornography & 1 \\
Encryption & 1 \\
Netiquette & 1 \\
Digital divide & 1 \\
\hline
\end{tabular}

If we consider the top categories, which appear in more than half of these books, it is obvious that the ethical issues which are perceived today as the most important may be summarised as follows (Table 3):

Table 3. Quoted ethical concerns

\begin{tabular}{ll}
\hline Broad Issue & Specific issue \\
\hline Classical & Privacy \\
Classical & Risks and security \\
Classical & Intellectual property rights \\
Classical & Responsibility, reliability and liability in designing information \\
& systems or software \\
Classical & Professional codes of ethics or of conduct \\
Classical & Computer crime \\
Recent Internet-related & Equity of access \\
Recent Internet-related & Digital divide \\
Recent Internet-related & Pornography \\
Recent Internet-related & Netiquette \\
\hline
\end{tabular}




\section{IFIP APPROACHES}

\subsection{Phase One: An IFIP Code for all member Societies or the creation of 'Spaces for discussion'?}

What support did IFIP provide for structuring educational material in this emerging area? Officially the community started to debate ethics in the late 1980s, when its New Delhi General Assembly suggested the development of an international Code of Ethics. Even earlier, IFIP-TC9, and more precisely WG9.2, worked in this area. The question was also under discussion in the Council of Europe. After turbulent debate the idea of an international code was abandoned in favour of a process that would take more into account the cultural, social and legal diversity of the member Societies (Berleur 2001). Interestingly, although IFIP abandoned the idea more than 10 years ago, selfregulation today is curiously considered a solution to regulate internationally that which cannot be regulated by law because of its intrinsic link to territoriality.

Analysis of the codes of member Societies was carried out and suggestions were made, first to consider the results and other topics when drafting a code, and secondly, to create 'spaces for discussion' where deep convictions might be shared and from which principles could be derived (Habermas 1992; Maesschalck 1994).

No less than 15 IFIP member societies have codes (24 codes altogether). We added 6 other professional non-IFIP codes. The major ethical concerns these codes consider as belonging to the deontology of the profession comprise five main domains (Berleur and Gevers 1996).

\section{Respectful general attitude}

This includes: respect for the interests/rights of those involved [15/30], respect for the prestige of the profession [11], respect for the interests/rights of the public [10], and respect for the welfare/health of the public and for the quality of life [10].

Personal (/institutional) qualities: conscientiousness, honesty and positive attitude, competence and efficiency

In practice conscientiousness and honesty are frequently encountered under expressions like: acceptance of responsibility [19] and integrity [26], respect for requirements, contracts or agreements [14] and conscientious work [11]. With regard to competence and efficiency two other terms are very common: professional development and training [19] or limitation of work to the field of competence [18]. 
Promotion of information privacy and data integrity Confidentiality [22] is required by nearly all the IFIP societies general codes [13/15]. Privacy in general [14] and respect for property rights [12] are appealed to often. No computer crime, no information piracy or misuse [7].

Production and flow of information

Flow of information to involved parties or people is required by the majority of the codes [23]. Information to the public [16] is also insisted upon. Almost half of codes calls for comprehensive information [14].

Attitude towards regulations

Regulations do not appear as a major theme. Less than half the codes require respect for the code [13], respect for the law [13], and respect for IT and professional standards [12]. Some consider sanctions against a breach of the code [9].

Clearly these codes contain general clauses and recommendations, which are not deeply rooted in ICT. Most clauses belong to general business ethics, except perhaps those related to privacy, data integrity, production and flow of information. Even these are the translation in the ICT field of the 'fair relationship with the client' in the field of business ethics.

IFIP recommended its member Societies should consider more ICTrelated topics - issues such as computer crime, the accountability and liability for the content of networked information and transborder intellectual property rights. It was also suggested they should study in depth some issues of much broader scope and see how they might be included in codes of conduct. These covered the unequal distribution of information; unequal access to technology; participation in decisions which affect life at home and work; how computer technology reinforces predominant power; denial or restriction of access to groups/individuals who lack the resources to participate in an increasingly market dominated system; poor cultural diversity which today pervades our information, media and communication systems; the necessity of majoring local cultural content requirements in network offerings; the importance of promoting culturally sensitive and multi-cultural interfaces; and involving cultural minorities in the design of socially significant information and communication systems (IFIP GA 1996).

As a result of this first phase, IFIP's General Assembly recommended the creation of 'spaces for discussion' in each member Society and the establishment of a permanent Special Interest Group (IFIP-SIG9.2.2) on Ethics of Computing. Their objectives were to keep alive the ethical question within the different IFIP constituencies and in all circles where IFIP members manifest their influence. They were asked to suggest themes and topics to be studied nationally or regionally. 


\subsection{Phase Two: Ethics and the Governance of the Internet}

After examination of IFIP member Societies codes, SIG9.2.2 analysed similar documents published 'outside its walls'. Many employed the old medieval term 'Charter', stressing their foundational character: 'Cyberspace and the American Dream: A Magna Carta for the Knowledge Age' (1994, Progress and Freedom Foundation, PFF); 'Proposal for an Internet charter: Rules and Courtesies of the Actors of the Internet' (France, 1997); Online Magna Charta, Charta of Freedom for Information and Communication', (1997, The Wartburg Charta); and the 'Intergovernmental Information Technology Leadership Consortium Charter' (1997, Council for Excellence in Government). Others, like 'Ten Commandments of the Computer Ethics Institute', used the majestic style of worship: 'Thou Shalt Not Use A Computer To Harm Other People. Thou Shalt Not Snoop Around In Other People's Computer Files'. The Internet Service providers associations were drafting their first codes (EuroISPA 1997; IAPCode 2001), and it was the time for a new approach to the problem of governing the Internet which spawned a fetish for the term 'governance'.

To record the analysis of these documents SIG9.2.2 adopted a grid commonly used for legal documents. This identifies the actors and the people concerned (ratione personae), the place where the law is applicable (ratione loci), the matters which are covered (ratione materiae), the rules for enforcement, including sanctions and procedures, and finally a 'miscellaneous' section.

Topics derived from analyses and which were considered ethical topics included (Rasmussen 2001):

- no illegal, dubious, harmful material, racial hatred, drug traffic, denial of crime against humanity;

- protection of children and of youth;

- confidentiality, privacy and other linked right such as access, correction of personal data;

- correctness, accuracy and fairness;

- respect, honesty, competence, sincerity, right information, work quality;

- no computer crime;

- fair trading, correct pricing information, consumer protection, consumer confidence, no unsolicited email advertising, reliable information, transparency, clear definition of liabilities;

- protection of intellectual property rights, copyright, trademark, patent;

- free speech, right to information and communication. 
Many of these topics were already mentioned earlier (Table 3).

These results were published and discussed during the 1998 IFIP-TC9 Fifth Human Choice and Computers international conference in Geneva and presented to the 1999 IFIP General Assembly in Kuala Lumpur through a monograph that was distributed to all the member Societies to promote discussion.

\subsection{Phase Three: Ethics and Self-regulation}

Between 1998 and 2001, IFIP-SIG9.2.2 collected nearly 40 additional self-regulation documents. These have been analysed according to the same analysis grid described above and the results have been cumulated with those from the analysis of the 30 IFIP and professional codes. This enabled the construction of a first inventory: Table 5 offers a detailed classification of all 70 documents (Berleur and Ewbank 2002).

Table 4. Classification of the inventory of self-regulation documents

\begin{tabular}{ll}
\hline Numerical Class & Category \\
\hline $\mathbf{1}$ & Informatics- Computing in general \\
1.1 & General principles \\
1.2 & Specific principles \\
$\mathbf{2}$ & For Professional Societies \\
2.1 & The Internet \\
2.1 & General principles \\
2.2 .1 & Specific principles \\
2.2 .2 & For Virtual Communities \\
2.2 .3 & For Different Actors \\
2.2 .4 & For (Associations of) Service Providers \\
2.2 .5 & For other Service Providers \\
2.2 .6 & For Governmental Services and Actors \\
2.2 .7 & For the Industry in general \\
2.2 .7 .1 & For Specific Sectors and Services \\
2.2 .7 .2 & Health Sector \\
2.2 .7 .3 & Publishing Sector \\
2.2 .7 .4 & e-Commerce Sector \\
2.2 .7 .5 & Software Publishers Sector \\
\hline
\end{tabular}

While 'general principles' codes remain rather fuzzy they do have a deontological content. They may include consideration of correctness as in the rules of Netiquette. In inviting the respect of others and other people's work they could be considered to belong to the tradition of professional ethics or fair conduct. But they are not so coercive. The virtual communities and service providers express concerns about 'illegal material' (child 
pornography and racist propaganda), the necessity of protecting youth, (especially against those who exploit their credulity) and manifest their commitment to cooperate with hotlines. They also mention data protection, confidentiality and e-mail secrecy and include clauses on no violence, hatred, or cruelty, respect for human dignity and no discrimination be it ethnic/religious or handicap related.

Clauses related to 'computer crime' or 'cyber-crime' abound. They cover illegal access, illegal interception, data interference, system interference, misuse of devices, computer-related forgery and fraud, offences related to child pornography, infringements of copyright and related rights, attempt and aiding or abetting, as focused today by the recent Convention $\mathrm{n}^{\circ} 185$ on Cybercrime (Council of Europe 2001).

These are the more ethical topics. Curiously, with codes becoming more sectoral, one could/might expect more specific clauses, since self-regulation is supposed to anticipate or supplement what cannot be included, for instance, in law because of its territoriality or lack of flexibility, or the rapid development of technology. What clearly emerges is the more contractual character of these documents and the insistence on practice in accordance with the standards of the profession.

Deontology clauses become 'terms of service'. The Code of Ethics of the Internet Health Care coalition requires candour and trustworthiness, quality of information, products, services, the best commercial practices (our emphasis) and the highest standards by health care professionals (Internet Healthcare Coalition 2000). In online publishing, the French Charter reaffirms the normal professional rules but also details the number of paragraphs that can be quoted under fair dealing provisions and specifies the rules related to links that may be created to online content. In electronic commerce, the 'Model Code of Conduct for Electronic Commerce' offers typical clauses found in good commercial practice: reliability of the information which is provided, systems and organisations and types of electronic signatures, as well as transparency in the communication, confidentiality and respect for intellectual property (ECP-NL 2001).

If there are real ethical clauses, the impression is that when we leave the general principles of the deontological approach for more specific principles expressed in contractual terms, ethics increasingly is absent. While selfregulation instruments are supposed to protect all parties they appear to protect only the authors. Our deep conviction is that they are more selfprotecting than self-regulating. The proliferation of codes of ethics and/or ethical conduct is not yet a sign of a 'rush towards ethics'.

If we want self-regulation to reflect real ethical concerns it must be scrutinised carefully. We have suggested that minimum requirements must be met and recommendations must be made on the level of self-regulation. 
Codes of general principles are not the same as sectoral ones. The titles and preambles must make explicit the status of those documents, and they must all be negotiated in a participatory manner.

Self-regulation is becoming a major ethical problem and must be debated openly. While it is trying to find its place in the normative order it still remains minimal if not minimalist and most of the time, it is promulgated to avoid a greater degree of statutory regulation. Is self-regulation an anticipation, or a supplement or a substitute for the law? What is its ethical content? From a democratic point of view how legitimate is self-regulation? Who drafts and elaborates the legislation? What role should the regulators take to protect citizen and customers?

\section{ETHICAL TOPICS FOR EDUCATIONAL PROGRAMMES}

Patently many questions are interwoven. Codes of ethics or of conduct may include matters which are all relevant for ethics but are already covered by proper regulatory instruments. The Convention on Cybercrime, the European Directives on 'electronic communications networks and services' and the US Digital Millenium Copyright Act are excellent examples.

What is covered, among other matters is the protection of content (by protecting intellectual property and related rights); and the protection of the transaction (via the electronic signature for proper identification), the authentication of messages, and their confidentiality.

The Cybercrime Convention protects exchanges from intrusions and from illicit or fraudulent acts. The European Directive on electronic commerce and the US Digital Millenium Copyright Act free intermediaries from liability regarding content. Essentially, all that is linked to business and commerce is 'under control'.

This means that we need to focus our attention on topics with a more ethical content. SIG 9.2.2 made its choices on two levels. The first was rather pragmatic: the level of the questions which are already under discussion (or 'under control') including the protection of the individual (as citizen and as consumer), and the protection of organisations and of society.

These questions include ethical content, but there is less emergency. The second level is linked to principles. It establishes as principles of judgement and choice the protection of human dignity, the vulnerability of the weakest or the underprivileged, and the sustainability of society.

Among the different topics SIG 9.2.2 has met in its analyses the following issues involved more ethical content (Table 5): 
Table 5. Topics with more ethical content

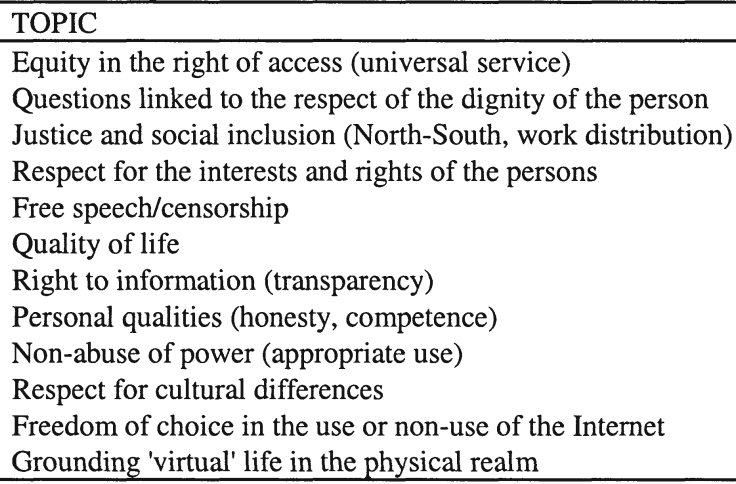

Compare the first summary of the current ethical topics (Table 3) with that of the present list (Table 5).

Originally privacy, intellectual property rights, responsibility, reliability and liability in designing information systems or software, professional codes of ethics or of conduct, and computer crime were mentioned. I have explained that recent literature mentions specific issues, which arise from the development of the Internet: equity of access, the digital divide, pornography and Netiquette.

While there are some new topics, there is a great deal of convergence or correspondence between Table 3 and Table 5 - a convergence illustrated in Table 6.

The topics certainly supplement the list outlined in the report 'Consequences of Computing: A Framework for Teaching the Social and Ethical Impact of Computing' which was discussed early in this paper.

Philippe Quéau, Director of Information and Informatics at UNESCO, concluded his speech to the 1999 Regulators summit by remarking:

"The structural imbalances of the world-wide Internet infrastructure, the deep inequalities in the access to information, the transnational oligopolies controlling the world-wide infostructure are major preoccupations for the regulator. A new form of regulation or of governance at the world level must be conceived in an ethical world-wide perspective, at the service of equity and of the human development." (Quéau, 1999)

Educational programmes must prepare people to meet these requirements. 
Table 6. Ethical issues - a summary

\begin{tabular}{|c|c|c|}
\hline $\begin{array}{l}\text { Most quoted ethical concerns } \\
\text { (Table 3) }\end{array}$ & $\begin{array}{l}\text { Topics with ethical content in self- } \\
\text { regulation documents (Table 5) }\end{array}$ & Under control \\
\hline Privacy & & USA? \\
\hline Risks and security & & $?$ \\
\hline Intellectual property rights & Respect for interests and rights & Yes \\
\hline $\begin{array}{l}\text { Responsibility, reliability and } \\
\text { liability in designing systems }\end{array}$ & & $?$ \\
\hline \multirow{3}{*}{$\begin{array}{l}\text { Professional codes of ethics or } \\
\text { conduct }\end{array}$} & Right to information (transparency) & \\
\hline & Personal qualities & \\
\hline & Non-abuse of power & \\
\hline Computer crime & & Yes \\
\hline Equity of access & $\begin{array}{l}\text { Equity in the right of access } \\
\text { ('Universal Service') }\end{array}$ & Europe.Direct \\
\hline Digital divide & $\begin{array}{l}\text { Justice and social inclusion } \\
\text { (North-South) }\end{array}$ & \\
\hline Pornography & $\begin{array}{l}\text { Questions linked to respect of dignity } \\
\text { of the person (protection of minors } \\
\text { and human dignity) }\end{array}$ & Self-regulation \\
\hline \multirow[t]{6}{*}{ Netiquette } & & $?$ \\
\hline & Free speech & $?$ \\
\hline & Quality of life & $?$ \\
\hline & Respect for cultural differences & $?$ \\
\hline & Freedom of choice re. Internet & $?$ \\
\hline & $\begin{array}{l}\text { Grounding virtual life in the physical } \\
\text { realm }\end{array}$ & $?$ \\
\hline
\end{tabular}

\section{A STEP ALONG THE WAY}

Our approach may appear rather pragmatic but quite normal in applied ethics, where preconceived ideas should be avoided. The process must be rational and promote discussion on cultural, social and legal differences.

The content of the list proposed in the report 'Consequences of Computing: A Framework for Teaching the Social and Ethical Impact of Computing' is acceptable provided the levels of social analysis are slightly reformulated to be made more homogeneous, and provided the list of ethical issues is expanded and ranked in terms of priorities. The social and ethical skills are worthy of consideration for teaching. The social skills suggested by the ImpactCS report are:

"Identifying and interpreting the social context of a particular implementation; identifying assumptions and values embedded in a 
particular system; and evaluating, by use of empirical data, a particular implementation of a technology."

whilst the proposed ethical skills are:

"Arguing from example, analogy, and counter-example; identifying stakeholders in concrete situations; identifying ethical issues in concrete situations; applying ethical codes to concrete situations; and identifying and evaluating alternative courses of action." (ImpactCS 1996)

Our intention was to call for vigilance, to support education in 'technology watching', because the Internet induces and introduces new and major social and ethical changes. Looking back on thirty years of 'Computers and Society' challenges and fifteen years of 'Ethics and Computing' issues, we can observe similarities in the concerns, but the list of problems are not comparable. Indeed one list circulated by 'People for Internet Responsibility' identifies 116 categories covering 7 pages of documentation (PFIR 2001). In 1976 the IFIP General Assembly, establishing its Technical Committee 9 on 'Relationships between Computers and Society' judged that two Working Groups would be sufficient to cover the main questions!

However, I would like also to share my perplexity. I stated that specific laws have been enacted recently primarily to protect e-Commerce. Intellectual property and related rights was also recommended as a major ethical issue for consideration. What of questions related to human dignity and the protection of children, or about racial hatred?

With regard to the first, the European Union published a 'Green paper on the Protection of Minors and Human Dignity in Audiovisual and Information Services', in 1996. This was followed up by the 'Council Recommendation on the development of the competitiveness of the European audiovisual and information services industry by promoting national frameworks aimed at achieving a comparable and effective level of protection of minors and human dignity' in 1998. Next came a 'Safer Internet Action Plan' in 1999 where public authorities have almost no role to play. Recently, in 2002, the European Parliament issued a report on the evaluation of the Council Recommendation. This clearly stated that it does not intend to undertake any legislative measure on the subject.

Regarding racial hatred, the "Digital Hate 2002 Report" from the Simon Wiesenthal Center identified 600 extremist and racist sites 1997 and over 3400 in 2002 (Wiesenthal 2002). Sites feature animated hate games, online enrolment for suicide bombers, Neo-Nazi online identity theft and other examples of transnational hate. Extremism and racism pervade the domain of 
games such as the Austrian KZ (Konzentrationslager) Manager (where Turks are killed in a concentration camp), or the Swedish Alrea Alpy (where the targets in the shooting gallery are black people.)

Privacy is also an issue that, although present since the very first days of the computers and society discussions, has always been interpreted differently on the two sides of the Atlantic. Negotiation about the application of articles 25 and 26 of the 1995 European Directive on data protection, and the obligation for third parties to have an 'adequate level of protection' resulted in the famous 'Safe Harbor' self-regulation principles (COM 2000). Law on one side, self-regulation on the other!

Who will decide what is most important from the ethical point of view? We will - together. Faithful to our philosophy of opening spaces of discussion where we share our values and convictions, as I have with you. It will be up to each of us to do the same with others. The next agenda for IFIP-SIG9.2.2 will be the question of ICT, justice and social ex/inclusion.

\section{REFERENCES}

ACM/IEEE-CS (1990) Computing Curricula 1991. Report of the ACM/IEEE-CS Joint Curriculum Task Force, ACM Press, IEEE Computer Society Press, December. pp. 69-71. ACM/IEEE-CS (2001) Computing Curricula 2001. Approved Final Draft of the Computer Science Volume, Joint Task Force on Computing Curricula, IEEE-CS/ACM, December.

[http://computer.org/education/cc2001/]

Berleur, J. (1996) Remarks on a 'Framework for Social and Ethical Issues' Report. In The Impact of Information Technology: From Practice to Curriculum, Y. Katz, D. Millin and B.Offir (eds.), Chapman \& Hall, pp. 108-117. See also: Same author, 'A Focus on the Main Issues...' Review of 'Computers in Context: A Framework for Presenting the Social and Ethical Impact of Computing. A Report from the ImpactCS Steering Committee'. In Computers and Society, ACM Special Interest group on Computers and Society, Volume 26, No. 1, March 1996, pp.7-8.

Berleur, J. and d'Udekem-Gevers, M. (1996) Codes of Ethics or of Conduct Within IFIP and Other Computer Societies. In Ethics of Computing: Codes, Spaces for Discussion and Law, J. Berleur and K. Brunnstein (eds.), Chapman \& Hall (now Kluwer), London. pp. 341.

Berleur, J. and d'Udekem-Gevers, M. (2001) Codes of Ethics/Conduct for Computer Societies: The Experience of IFIP. In Technology and Ethics, A European Quest for Responsible Engineering, P. Goujon and B. Heriard Dubreuil (eds.). European Ethics Network, Peeters, Leuven, Belgium. pp. 327-350.

Berleur, J. and Ewbank de Wespin, T. (2002) Self-regulation: Content, Legitimacy and Efficiency - Governance and Ethics. In Human Choice and Computers, Issues of Choice and Quality of Life in the Information Society, K. Brunnstein and J. Berleur (eds.). Proceedings of the IFIP-HCC6 Conference, $17^{\text {th }}$ World Computer Congress, Montréal, 
August 2002, Kluwer Academic Publ. pp. 89-108. [http://www.info.fundp.ac.be/ jbl/IFIP/sig922/selfreg.html]

Commission Decision 2000/520/EC of 26.7.2000 pursuant to Directive 95/46/EC of the European Parliament and of the Council on the adequacy of the protection provided by the Safe Harbor privacy principles and related frequently asked questions issued by the US Department of Commerce - Official Journal of the European Communities, L 215/7 of 25.8.2000.

Council of Europe (2001) Convention on Cybercrime, Convention No.185, opened to signature on November 13, 2001.

[http://convention.coe.int]

Electronic Commerce Platform Nederland (2001) Code of Conduct for electronic commerce, (Draft 4.0, 2001)

[http://www.ecp.nl/ENGLISH/publication/cocdraft4.0ENG.pdf]

Ermann, M. D., Williams, M. B. and Gutierrez, C. (1990) Computers, Ethics and Society, Oxford University Press, New York, Oxford.

European Internet Services Providers Association (1997). Codes of Conduct of the Member Associations.

[http://www.eurooispa.org]

Forester, T. and Morrison, P.(1994) Computer Ethics: Cautionary Tales and Ethical Dilemmas in Computing, The MIT Press, $2^{\text {nd }}$ edition.

Habermas, J. (1992) De l'éthique de la discussion, Paris, Cerf, 1992. [Orig.: Erlauterungen zur Diskursethik, Engl. Transl.: Justification and Application: Remarks on Discourse Ethics, Cambridge Mass.: The MIT Press, 1993].

IAPCode (2001) Selfregulation.info, Programme in Comparative Media Law and Policy, Centre for Socio-Legal Studies, Wolfson College, Oxford University. [http://www.selfregulation.info/]

IFIP GA (1996) Recommendations Regarding Codes of Ethics/Conduct for IFIP Computers and Society. IFIP General Assembly, Hamburg, September $6^{\text {th }}$, 1994, in: Ethics of Computing: Codes, Spaces for Discussion and Law, J. Berleur and K. Brunnstein (eds.). Chapman \& Hall (now Kluwer), London. pp. 257-268.

Project ImpactCS Steering Committee (1996) 'The Consequences of Computing: A Framework for Teaching the Social and Ethical Impact of Computing'. In Computers and Society, ACM SIGCAS, vol. 26, No. 1. pp. 3-10. See also: Huff, C. and Martin, C. D. 'Computing Consequences: A Framework for Teaching Ethical Computing'. In Communications of the ACM, December 1995, vol. 38, Nr. 12, pp. 75-84.

(Internet Healthcare Coalition, 2000): Internet Healthcare Coalition, eHealth Code of Ethics. 2000.

[http://www.ihealthcoalition.org/ethics/]

Johnson, D. G. and Snapper J. W. (1995) Ethical Issues In the Use of Computers, Wadsworth Publishing Company. (Out of print).

Johnson, D. G. $(1985 ; 1994 ; 2001)$ Computer Ethics, Englewood Cliffs, N. J.: Prentice-Hall, Inc.

Johnson, D. and Nissenbaum, H. (eds.) (1995) Computers, Ethics and Social Values, Prentice Hall.

Kallman, E. K. and Grillo, J. P. (1993) Ethical Decision and Information Technology. An Introduction with Cases, Mac Graw-Hill.

Kizza, J. M. (1998), Ethical and Social Issues in the Information Age, Springer.

Langford, D. (ed.) (2000) Internet Ethics, Palgrave - McMillan Press. 
Maesschalck, M. (1994) Pour une éthique des convictions. Religion et rationalisation du monde vécu. Publications des Facultés universitaires Saint-Louis, Coll. Philosophie, Bruxelles.

Moor, J. H. (1985) What is computer ethics? In Computers and Ethics, W. T. Bynum (ed.). Metaphilosophy, Volume 16, No. 4. Basil Blackwell, Oxford and New York. pp. 266-275.

Oz, E. (1994) Ethics for the Information Age, Business and Educational Technologies, Wm. C. Brown Publishing, Dubuque, IA.

PFIR - People For Internet Responsibility (2001) ISSUES, Version of July 4. [http://pfir.org/issues]

Rasmussen, L. B., Beardon, C. and Munari, S. (eds.) (2001) Computers and Networks in the Age of Globalization. Proceedings of the $5^{\text {th }}$ IFIP-TC9 'Human Choice and Computers' Conference, Kluwer Academic Publ., 2001: see the papers 'Ethics and the Governance of the Internet' and 'The Process of Ethics', pp. 141-154 and 361-379.

Spinello, R. (2000) Cyberethics. Morality and Law in Cyberspace, Jones and Bartlett Publishers, Sudbury Mass.

Quéau, P. (1999) 'Internet: Vers une régulation mondiale'. UNESCO, World Summit of regulators, Internet and the New Services, Paris.

[http://www.unesco.org/webworld/news/991201_queau_csa.shtml]

Weizenbaum, J. (1976) Computer Power and Human Reason - From Judgment to Calculation, W. H. Freeman and Coy. San Francisco. (Penguin Books edition in 1984, with a new Preface).

Simon Wiesenthal Center (2002) Press information, 20 May, 2002. [http://www.wiesenthal.com/social/press/pr_item.cfm?ItemID=5723] 